\title{
Front Matter: Volume 8289
}

, "Front Matter: Volume 8289," Proc. SPIE 8289, The Engineering Reality of Virtual Reality 2012, 828901 (8 March 2012); doi: 10.1117/12.928077

SPIE Event: IS\&T/SPIE Electronic Imaging, 2012, Burlingame, California, United SPIE. States 


\section{PROCEEDINGS \\ IS\&T/SPIE \\ Eleatronic \\ Imaging \\ Science and Technology}

\section{The Engineering Reality of Virtual Reality 2012}

Ian E. McDowall

Margaret Dolinsky

Editors

24-25 January 2012

Burlingame, California, United States

Sponsored and Published by

IS\&T-The Society for Imaging Science and Technology

SPIE 
The papers included in this volume were part of the technical conference cited on the cover and title page. Papers were selected and subject to review by the editors and conference program committee. Some conference presentations may not be available for publication. The papers published in these proceedings reflect the work and thoughts of the authors and are published herein as submitted. The publishers are not responsible for the validity of the information or for any outcomes resulting from reliance thereon.

Please use the following format to cite material from this book:

Author(s), "Title of Paper," in The Engineering Reality of Virtual Reality 2012, edited by lan E. McDowall, Margaret Dolinsky, Proceedings of SPIE-IS\&T Electronic Imaging, SPIE Vol. 8289, Article CID Number (2012).

ISSN 0277-786X

ISBN 9780819489364

Copublished by

SPIE

P.O. Box 10, Bellingham, Washington 98227-0010 USA

Telephone +1 3606763290 (Pacific Time) · Fax +1 3606471445

SPIE.org

and

IS\&T-The Society for Imaging Science and Technology

7003 Kilworth Lane, Springfield, Virginia, 22151 USA

Telephone +1 7036429090 (Eastern Time) · Fax +1 7036429094

imaging.org

Copyright (c) 2012, Society of Photo-Optical Instrumentation Engineers and The Society for Imaging Science and Technology.

Copying of material in this book for internal or personal use, or for the internal or personal use of specific clients, beyond the fair use provisions granted by the U.S. Copyright Law is authorized by the publishers subject to payment of copying fees. The Transactional Reporting Service base fee for this volume is $\$ 18.00$ per article (or portion thereof), which should be paid directly to the Copyright Clearance Center (CCC), 222 Rosewood Drive, Danvers, MA 01923. Payment may also be made electronically through CCC Online at copyright.com. Other copying for republication, resale, advertising or promotion, or any form of systematic or multiple reproduction of any material in this book is prohibited except with permission in writing from the publisher. The CCC fee code is $0277-786 \mathrm{X} / 12 / \$ 18.00$.

Printed in the United States of America.

Paper Numbering: Proceedings of SPIE follow an e-First publication model, with papers published first online and then in print and on CD-ROM. Papers are published as they are submitted and meet publication criteria. A unique, consistent, permanent citation identifier (CID) number is assigned to each article at the time of the first publication. Utilization of CIDs allows articles to be fully citable as soon as they are published online, and connects the same identifier to all online, print, and electronic versions of the publication. SPIE uses a six-digit CID article numbering system in which:

- The first four digits correspond to the SPIE volume number.

- The last two digits indicate publication order within the volume using a Base 36 numbering system employing both numerals and letters. These two-number sets start with 00, 01, 02, 03, 04, 05 , 06, 07, 08, 09, OA, OB ... 0Z, followed by 10-1Z, 20-2Z, etc.

The CID number appears on each page of the manuscript. The complete citation is used on the first page, and an abbreviated version on subsequent pages. Numbers in the index correspond to the last two digits of the six-digit CID number. 


\section{Contents}

vii Conference Committee

\section{SESSION 1 CONTEXT AWARENESS AND IMMERSION}

828902 Foreign language learning in immersive virtual environments [8289-01]

B. Chang, L. Sheldon, M. Si, A. Hand, Rensselaer Polytechnic Institute (United States)

828903 Virtual reality technology prevents accidents in extreme situations [8289-02]

Y. Badihi, M. N. Reiff, S. Beychok, Jerusalem College of Technology (Israel)

828904 Motion parallax in immersive cylindrical display systems [8289-03]

N. Filliard, Lab. of Physiology of Perception and Action, CNRS, Collège de France (France) and Renault Technocentre (France); G. Reymond, Renault Technocentre (France); A. Kemeny, Renault Technocentre (France) and Arts et Métiers ParisTech, Lab. Electronique, Informatique et Image, CNRS (France); A. Berthoz, Lab. of Physiology of Perception and Action, CNRS, Collège de France (France)

\section{SESSION 2 COMMUNICATING PERSPECTIVE THROUGH VR}

828905 Meta!Blast computer game: a pipeline from science to 3D art to education [8289-04]

W. Schneller, P. J. Campbell, D. Bassham, E. S. Wurtele, lowa State Univ. (United States)

828906 Learning immersion without getting wet [8289-05]

J. C. Aguilera, Univ. of Plymouth (United Kingdom) and Adler Planetarium and Astronomy Museum (United States)

828908 Female artists and the VR crucible: expanding the aesthetic vocabulary [8289-07] J. F. Morie, The Univ. of Southern California (United States)

\section{SESSION 3 REFACING VR}

828909 Markerless 3D facial motion capture system [8289-08]

Y. Hwang, J.-B. Kim, X. Feng, W.-C. Bang, T. Rhee, J. D. K. Kim, C. Kim, Samsung Advanced Institute of Technology (Korea, Republic of)

8289 OA Capturing geometry in real-time using a tracked Microsoft Kinect [8289-09]

D. Tenedorio, M. Fecho, J. Schwartzhaupt, R. Pardridge, J. Lue, J. P. Schulze, Univ. of California, San Diego (United States)

$8289 \mathrm{OB} \quad$ An example-based face relighting [8289-10]

H. Shim, Samsung Advanced Institute of Technology (Korea, Republic of); T. Chen, Cornell Univ. (United States) 
8289 OC Heteronyms and avatars: a self-reflective system for artistic activity [8289-11]

E. Ayiter, Sabanci Univ. (Turkey)

\section{SESSION 4 VR HYBRIDS: AUGMENTED REALITY}

8289 OD ManifestAR: an augmented reality manifesto [8289-12]

J. C. Freeman, Emerson College (United States)

8289 OE Invisible waves and hidden realms: augmented reality and experimental art [8289-13]

S. Ruzanka, Rensselaer Polytechnic Institute (United States)

8289 OF Immersive realities: articulating the shift from VR to mobile AR through artistic practice [8289-14]

T. Margolis, T. Cornish, Univ. of California, San Diego (United States); R. Berry, Univ. of Technology, Sydney (Australia); T. A. DeFanti, Univ. of California, San Diego (United States)

8289 OG MetaTree: augmented reality narrative explorations of urban forests [8289-15]

R. West, T. Margolis, Univ. of California, San Diego (United States); J. O'Neil-Dunne, The Univ. of Vermont (United States); E. Mendelowitz, Smith College (United States)

\section{SESSION 5 VIEWING VIRTUAL EXPERIENCES}

$8289 \mathrm{OH} \quad$ Reordering virtual reality: recording and recreating real-time experiences [8289-16]

M. Dolinsky, W. Sherman, E. Wernert, Y. C. Chi, Indiana Univ. (United States)

$8289 \mathrm{OI}$ The cognitive implications of virtual locomotion with a restricted field of view [8289-18]

W. E. Marsh, J. W. Kelly, V. J. Dark, J. H. Oliver, lowa State Univ. (United States)

\section{SESSION 6 EDUCATIONAL PATHWAYS IN VR}

8289 OK LVC interaction within a mixed-reality training system [8289-20]

B. Pollock, E. Winer, S. Gilbert, lowa State Univ. (United States); J. de la Cruz, U.S. Army RDECOM/STTC (United States)

$8289 \mathrm{OL} \quad$ Immersive volume rendering of blood vessels [8289-21]

G. Long, H. S. Kim, A. Marsden, Y. Bazilevs, J. P. Schulze, Univ. of California, San Diego (United States)

$82890 \mathrm{M}$ A virtual reality interface for pre-planning of surgical operations based on a customized model of the patient [8289-22]

M. Witkowski, J. Lenar, R. Sitnik, Warsaw Univ. of Technology (Poland); N. Verdonschot, Univ. Twente (Netherlands) and Radboud Univ. Nijmegen Medical Ctr. (Netherlands)

\section{INTERACTIVE PAPER SESSION}

$8289 \mathrm{ON}$ Prediction of visually perceived location using reaching action and effect of reaching distance on it [8289-23]

M. Suzuki, K. Takazawa, K. Uehira, H. Unno, Kanagawa Institute of Technology (Japan) 
828900 An innovative multimodal virtual platform for communication with devices in a natural way [8289-24]

C. R. Kinkar, R. Golash, A. R. Upadhyay, Sagar Institute of Research, Technology \& Science (India)

8289 OP Composite lay-up process with application of elements of augmented reality [8289-25]

J. Novák-Marcinčin, J. Barna, M. Janák, V. Fečová, L. Nováková-Marcinčinová, Technical Univ. of Kosice (Slovakia)

Author Index 
Downloaded From: https://www.spiedigitallibrary.org/conference-proceedings-of-spie on 26 Apr 2023

Terms of Use: https://www.spiedigitallibrary.org/terms-of-use 


\title{
Conference Committee
}

\author{
Symposium Chairs \\ Majid Rabbani, Eastman Kodak Company (United States) \\ Gaurav Sharma, University of Rochester (United States)
}

Conference Chairs

Ian E. McDowall, Fakespace Labs Inc. (United States)

Margaret Dolinsky, Indiana University (United States)

Session Chairs

1 Context Awareness and Immersion

Ian E. McDowall, Fakespace Labs Inc. (United States)

2 Communicating Perspective through VR

Margaret Dolinsky, Indiana University (United States)

3 Refacing VR

Ian E. McDowall, Fakespace Labs Inc. (United States)

$4 \quad$ VR Hybrids: Augmented Reality

Todd Margolis, University of California, San Diego (United States)

Margaret Dolinsky, Indiana University (United States)

$5 \quad$ Viewing Virtual Experiences

Ian E. McDowall, Fakespace Labs Inc. (United States)

6 Educational Pathways in VR

Margaret Dolinsky, Indiana University (United States) 
Downloaded From: https://www.spiedigitallibrary.org/conference-proceedings-of-spie on 26 Apr 2023

Terms of Use: https://www.spiedigitallibrary.org/terms-of-use 